\title{
ЩОДО ДОЦІЛЬНОСТІ ВВЕДЕННЯ У КЛІНІЧНУ ПРАКТИКУ ОКРЕМОЇ ШКАЛИ ОБ'ЄКТИВНОГО ОЦІНЮВАННЯ ЗАГАЛЬНОГО СТАНУ ПАЦІЄНТА
}

\author{
๑В. В. Франчук, М. В. Франчук \\ ДВНЗ «Тернопільський державний медичний університет імені І. Я. Горбачевського МОЗ України»

\begin{abstract}
РЕЗЮМЕ. В статті з судово-медичної експертної точки зору обґрунтовується необхідність створення та впровадження у повсякденну клінічну практику уніфікованої шкали оцінки загального стану пацієнта.

КЛЮчОВІ СЛОВА: судово-медична експертиза, медична документація, оцінка загального стану пацієнта.
\end{abstract}

Вступ. Під час розслідування та судового розгляду кримінальних справ, порушених у випадках неналежного виконання лікарями своїх професійних обов'язків, вирішальне значення для доведення або виключення вини медичного працівника має первинна медична документація [1]. Як важливе джерело доказу у кримінальній справі, історія хвороби пацієнта (наслідки лікування якого були невдалими), результати медичних обстежень, аналізів чи медичних маніпуляцій, обов'язково вилучаються слідчим з метою докладного вивчення. Розслідування таких «лікарських справ» $є$ достатньо складним, оскільки потребує з'ясування багатьох спеціальних медикоправових питань, які можуть бути вирішені виключно під час проведення комісійної судовомедичної експертизи $[2,3]$. До складу комісії таких експертів залучаються найкваліфікованіші лікарі судові медики та клініцисти, які, в результаті ретельного вивчення наданих слідчим медичних документів, дають висновок про правильність чи помилковість дій медичного персоналу, порушення діючих стандартів медичної допомоги, повноту та обсяг проведеного лікування тощо $[4,5]$. Як правило, у кожному випадку дефектної медичної допомоги слідству необхідно встановити стан пацієнта до моменту настання шкідливих наслідків, під час лікування чи подальшого лікарського спостереження, що дозволяє зробити висновок про професійність дій медичних працівників, отже - довести або спростувати їх вину. Оцінюючи загальний стан одного і того ж хворого, лікуючі лікарі зазвичай використовують в історії хвороби різні терміни (наприклад, «близький до задовільного», «не порушений», «відносно задовільний» тощо), що під час судово-медичного експертного вивчення такої історії хвороби не дає змоги визначити, в якому саме стані перебував пацієнт, а відтак - призводить до плутанини. Крім того, у клінічній практиці відсутні об'єктивні критерії загального стану пацієнта. Такі критерії не відображені також і у відповідних наказах, відомчих протоколах та стандартах надання медичної допомоги МОЗ України [6-8]. Тобто визначення загального стану лікар формулює на власний розсуд, а отже суб'єктивно, що утруд- нює експертне з'ясування істинного стану пацієнта. Відомі сьогодні шкали об'єктивного оцінювання мають вибірковий характер (шкала Апгар - для новонароджених, шкала Глазго - для коматозних станів тощо), тоді як уніфікованої шкали оцінки саме загального стану хворого, яку можна було 6 застосувати до будь-якого пацієнта, не існує.

Результати і обговорення. 3 огляду на вищенаведене, пропонуємо розробити таку шкалу (яку назвати «Шкала загального стану» - скорочено «ШЗС»), яка була 6 оптимальною для визначення загального стану будь-якого хворого, як соматичного, так і травматологічного чи хірургічного, як жінок, так і чоловіків, дорослих і підлітків. В основу цієї шкали доцільно покласти оцінювання за певними критеріями трьох основних життєво важливих систем організму (серцево-судинної, дихальної та ЦНС). Стан кожної із цих систем зручно визначати у балах, від 0 до 3, на підставі констатації лікарем простих, доступних і загальновживаних у повсякденній клінічній практиці показників стану гемодинаміки (частоти пульсу, величини артеріального тиску, шокового індексу), дихання (частоти дихальних рухів, особливостей самого дихання), функціонування центральної нервової системи (наявності чи відсутності свідомості, особливостей рефлекторної діяльності). Застосовуючи цю шкалу (ШЗС) лікуючий лікар під час огляду хворого може констатувати і цілком обґрунтовано зазначити у історії хвороби наступні чотири можливих загальних стани пацієнта: задовільний, середньої тяжкості, тяжкий та вкрай тяжкий. Діагностика кожного з цих видів можливих загальних станів хворого повинна ґрунтуватись на встановленні лікарем загальної кількості балів за функціональний стан основних систем життєдіяльності.

Оцінюючи стан серцево-судинної системи зручно керуватись наступною градацією: за умови фізіологічної норми, як для чоловіків, так і жі-



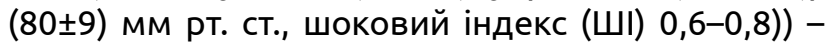
нараховувати 3 бали; (пульс - (90-100) уд/хв., АТ

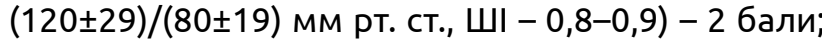

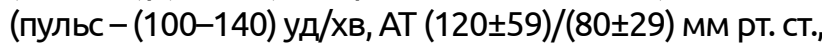


Огляди літератури, оригінальні дослідження, погляд на проблему

ШІ-1) - 1 бал; (ниткоподібний пульс або його відсутність, систолічний тиск нижче 60 мм рт. ст., Ш >1) - 0 балів.

При оцінці стану дихальної системи: дихання самостійне, частота дихання (ЧД) 18-20 - 3 бали;


хання несамостійне або наявність його патологічних видів (Чейн-Стокса, Біота, Куссмауля тощо) - 1 бал; відсутність дихання - 0 балів.

Діагностуючи стан ЦНС, пропонуємо враховувати наступні дані: свідомість ясна, сухожилкові та зіничний рефлекси викликаються, відсутність патологічних рефлексів - 3 бали; свідомість потьмарена, анізорефлексія чи наявність нечітких патологічних рефлексів при збереженні зіничного рефлексу - 2 бали; сопор, наявність грубих патологічних знаків, зіничний рефлекс в'ялий - 1 бал; (кома, відсутність рефлексів в т.ч. зіничного) - 0 балів.

Отримана кількість балів по кожній з систем додається. Таким чином, максимальну кількість балів за цією шкалою будуть мати хворі, стан яких відповідає їх віковій нормі або близький до такої норми (8-9 балів). Найнижча кількість балів буде характерною для термінального стану. Відповідно до запропонованої шкали (ШЗС), кожний з чотирьох видів можливих загальних станів градуюється наступним чином: наявність у пацієнта 8-9 балів відповідає задовільному загальному стану, 6-7 балів свідчить про середню тяжкість, 3-5 балів - тяжкий стан, 2 бали і менше - вкрай тяжкий.

Визначивши конкретну кількість балів, лікуючий лікар не буде вагатись, чи загальний стан хворого «близький до середнього» чи «близький до задовільного». Певна кількість балів у пацієнта, отримана лікарем при застосуванні шкали (Ш3С), дозволить точно, об'єктивно і науково обгрунто- вано визначити конкретний вид загального стану пацієнта. Окремо необхідно зауважити, що практикуючі лікарі нерідко вважають недоречним вживання терміну «задовільний стан» стосовно пацієнтів з хронічними захворюваннями, які поступають у стаціонар на планове обстеження і на момент госпіталізації є практично здоровими. Лікарі схиляються до думки, що загальний стан таких хворих у історії хвороби доцільно визначати як «відносно здоровий». Однак, про негативне медико-правове тлумачення подібних «розмитих» термінів згадувалось вище. Тому, на нашу думку, загальний стан пацієнтів з хронічними хворобами у медичних документах слід визначати все ж таки як «задовільний».

Висновок. 1. Лікар, оглядаючи хворого і застосовуючи шкалу оцінки загального стану пацієнта (ШЗС), яка ґрунтується на простих показниках функціонування основних систем життєдіяльності, має змогу доступно і об'єктивно констатувати певний конкретний стан пацієнта.

2. Оцінювати загальний стан хворого лікарі повинні уніфіковано, не на власний розсуд, а науково обґрунтовано, на підставі однакових для кожного лікаря підходів та тотожних для кожного пацієнта критеріїв.

3. Застосування запропонованої шкали (Ш3С) у повсякденній клінічній роботі дозволить уникати розбіжностей під час діагностики загального стану одного і того ж пацієнта, адекватно відображати стан хворого протягом всього періоду медичного спостереження. Такий підхід унеможливить термінологічну плутанину у медичних документах що, в свою чергу, допоможе у встановленні істини у справах, пов'язаних з неналежним виконанням своїх професійних обов'язків медичними працівниками.

\section{ЛІТЕРАТУРА}

1. Антонов С. Роль медицинской документации как доказательства в гражданском и уголовном судопроизводстве / С. Антонов // Медична практика: організаційні та правові аспекти. - 2011. - № 4. - С. 31-35.

2. Завальнюк А. Х. Етично-правові аспекти лікарської діяльності в Україні : монографія / А. Х. Завальнюк, Г. Ф. Кривда, І. О. Юхимець. - Одеса : Астропринт, 2008. - 192 с.

3. Завльнюк А. Х. Професійні правопорушення медичних працівників: аналіз ситуації, зміст поняття, пропозиції/ А. Х. Завальнюк, І. О. Юхимець, О. Ф. Кравець // Український судово-медичний вісник. - 2009. - № 2. - С. 30-34.

4. Москаленко В. Ф. Медичне законодавство: правова регламентація лікарської діяльності / В. Ф. Москаленко, Б. В. Михайличенко. - К.: ВСВ «Медицина». - 2011. - 495 с.

5. Хміль І. Ю. Законодавче забезпечення лікарської діяльності : навч. посібник / І. Ю. Хміль, Б. В. Михайличенко, О. І. Артеменко. - К. : ВСВ «Медицина», 2010. - 208 с.
6. Про затвердження загальних вимог щодо проведення медичного сортування постраждалих і хворих та форм медичної документації : Наказ МОЗ України від 5.06.2012 р. № 884/21196 [Електронний ресурс] / Режим доступу : http://www. moz.gov.ua/ua/portal/ dn_20120518_366.html

7. Про затвердження та впровадження медикотехнологічних документів зі стандартизації екстреної медичної допомоги : Наказ МОЗ України від 15.01.2014 р. № 34 [Електронний ресурс] / Режим доступу : http:// www. moz.gov.ua/ua/portal/dn_20140115_0034.html

8. Про затвердження та впровадження медикотехнологічних документів зі стандартизації медичної допомоги при геморагічному інсульті : Наказ МОЗ України від 17.04.2014 р. № 275 [Електронний ресурс] / Режим доступу : http://www.moz.gov.ua/ua/portal/ dn_20140417_0275.html 
Огляди літератури, оригінальні дослідження, погляд на проблему

ABOUT THE SCALE OF THE OBJECTIVE ASSESSMENT OF PATIENT'S GENERAL STATUS AND ITS NECESSITY FOR CLINICAL PRACTICE

@V. V. Franchuk, M. V. Franchuk

I. Horbachevsky Ternopil State Medical University

SUMMARY. A necessity of the compatible Scale for the assessment of the patient's general status is proved. An importance of its implementation into routine clinical practice from the angle of forensic examination is confirmed too.

KEY WORDS: forensic medical examination, medical documentation, assessment of the patient's general status.

Отримано 25.07.2016 